\title{
ACORDO INTERNACIONAL: A RELAÇÃO ENTRE LEGISLATIVO E EXECUTIVO TRADUZIDA EM NÚMEROS 12
}

\author{
Ronaldo Quintanilha da Silva ${ }^{3}$ \\ Cleiton Paiva Cabral Reges 4
}

\begin{abstract}
RESUMO
Neste artigo, demonstrou-se a relação entre os poderes Executivo e Legislativo no processo de construção dos acordos internacionais. Assim, o ato nasce da cooperação homogênea entre os dois poderes, alicerçado no princípio da separação dos poderes. Em relação à peculiar tramitação legislativa dos tratados internacionais, estruturou-se uma base de dados com as mensagens enviadas, sobre a qual se aplicaram procedimentos para identificar o fluxo de tramitação, considerando-se "tempo", "grupos temáticos", "regime de tramitação" e "comissões". Ao final, encontrou-se a média do tempo de tramitação dos acordos, inclusive retirando-se os outliers, e constatou-se, entre outras conclusões, que apenas trinta por cento dos acordos assinados são encaminhados para a apreciação do Congresso Nacional (Câmara dos Deputados e Senado Federal).
\end{abstract}

Palavras-chave: Poderes. Acordos internacionais. Processo legislativo. Câmara dos Deputados. Senado Federal.

\begin{abstract}
In this article the relation between the Executive and Legislative branches in the process of construction of the international acts was demonstrated. Thus, the act is born of the homogeneous cooperation of the branches, based on the principle of the separation of the branches. About the peculiar legislative process of the international treaties, a database with the sent messages was structured, on which procedures were applied to identify the flow of processing, considering "time", "thematic groups", "regime of procedure" and "committees". At the end, the average time for negotiating agreements, including the withdrawal of outliers, was found, and we reached the conclusion, among other conclusions, that only thirty percent of the signed agreements were submitted to the National Congress for consideration.
\end{abstract}

Keywords: Branches. International acts. Legislative process. Chamber of Deputies. Federal Senate.

\section{RESUMEN}

En este artículo, se demostró la relación entre los poderes Ejecutivo y Legislativo en el proceso de construcción de los acuerdos internacionales. Así, el acto nace de la cooperación homogénea entre los poderes, basada en el principio de la separación de los poderes. Acerca de la peculiar tramitación legislativa de los tratados internacionales, se estructuró una base de datos con los mensajes enviados, en la cual se aplicaron procedimientos para identificar el flujo de tramitación, considerando "tiempo", "grupos temáticos", "régimen de tramitación" y "comisiones". Al final, se encontró el promedio del tiempo de tramitación de los acuerdos, incluso retirándose los outliers, y se constató, entre otras conclusiones, que apenas treinta por ciento de los acuerdos firmados son encaminados para la apreciación del Congreso Nacional (Cámara de Diputados y Senado Federal).

Palabras clave: Poderes. Acuerdos internacionales. Proceso Legislativo. Cámara de los Diputados. Senado Federal.

\footnotetext{
${ }^{1}$ Enviado: 16/10/2017. Aceito: 05/01/2018.

${ }^{2}$ DOI: http://dx.doi.org/10.5380/recp.v9i1.55839

3 Aluno especial do Mestrado em Poder Legislativo promovido pelo CEFOR/CD (Centro de Formação, Aperfeiçoamento e Treinamento da Câmara dos Deputados) e Pós-graduado em orçamento público pelo Instituto Serzedêllo Corrêa do Tribunal de Contas da União. Analista legislativo da Câmara dos Deputados Email: roquintanilha@gmail.com

${ }^{4}$ Bacharel em direito pelo IESB Centro Universitário. Assessor técnico jurídico nas temáticas de direito e processo legislativo na Câmara dos Deputados. Email: cleiton.reges@gmail.com
} 
SILVA, R. Q; REGES, C. P. C. Acordo internacional: a relação entre legislativo e executivo traduzida em números

\title{
1. INTRODUÇÃ̃ ${ }^{5}$
}

\author{
"A pátria não é ninguém: são todos; e cada qual tem no seio dela o \\ mesmo direito à ideia, à palavra, à associação.” (Rui Barbosa $)^{6}$
}

A relação entre os três poderes está em evidência desde a sua construção teórica elaborada por Aristóteles e, mais tarde, aperfeiçoada por Montesquieu. Os Acordos Internacionais ${ }^{7}$ são frutos dessa relação, um trabalho de cooperação entre órgãos e instituições de ambos os lados - uma intercalação funcional que dura séculos e tem sido cada vez mais testada e coloca à prova. Traduzir essa relação em números, fazer reflexões sobre a peculiar tramitação dos acordos, observar a variável "tempo" e a atuação do Executivo na promulgação são os objetivos desta pesquisa.

Buscou-se demonstrar, na prática, a cooperação entre os poderes durante o processo legislativo de tramitação dos tratados internacionais, em especial quanto ao tempo de tramitação da matéria, dentro das regras impostas. Além disso, visamos atualizar os números quantitativos do processo legislativo, os quais são encontrados em estudos de Cavalcanti Júnior (2015), Camino (2014) e Souza (2010), e examinar se o teor dos acordos (como Penal, Meio Ambiente e de Economia) influencia no tempo de tramitação da matéria.

O artigo está dividido em partes: esta introdução, que também detalha a metodologia e o problema de pesquisa; uma segunda parte, em que se abordam a definição de "acordo" e a relação entre os poderes, inclusive as fases do processo legislativo de acordos intenacionais; e a última, em que se expõem os achados da presente pesquisa e as reflexões acerca deles, para, então, apresentarem-se as conclusões a esse respeito.

\subsection{METODOLOGIA}

Quanto ao método, a pesquisa pode ser dividida, segundo Gil (2008, p. 27), em uma parte descritiva, ao desenhar o processo legislativo, com suas instituições, atores e regras, além de procurar descobrir a existência de associações entre variáveis; e em uma parte explicativa, ao tentar, por intermédio da variável "tempo", comparar a velocidade de atuação em cada uma das etapas e responder, por exemplo, ao questionamento sobre a viabilidade de

\footnotetext{
5 Agradecemos os comentários e as críticas preciosas dos pareceristas, que, desde o início, destacaram a relevância do tema e ainda contribuíram para aperfeiçoar o artigo.

${ }^{6}$ Barbosa (1903, p. 360).

${ }^{7}$ Utilizar-se-ão as expressões "tratado" e "acordo" como sinônimos.
} 
mudança do regime de tramitação — além de ainda tentar explicar os fatores que influenciam o processo, como a criação da Comissão Mista de Representação do Parlamento do Mercosul.

Para empreender a pesquisa, utilizaram-se os sistemas de legislação disponível na Câmara dos Deputados e os portais da própria Câmara dos Deputados, do Senado Federal, do Planalto e do Itamaraty na internet. Deve-se registrar, ainda, a dificuldade de trabalhar com os sistemas das duas Casas, devido à falta de padronização entre eles, já observada por Amaral (2009, p. 130). Aproveitou-se também a pesquisa realizada pelo Centro de Documentação e Informação (CEDI) da Câmara dos Deputados, que extraiu as mensagens encaminhando acordos desde 1988 até 9 de maio de $2017 .^{8}$

Inicialmente, foi feita uma pesquisa bibliográfica sobre o assunto, com foco no processo legislativo do Congresso Nacional. Depois, com base no levantamento inicial de todas as mensagens enviadas contendo acordos internacionais desde 1988 até maio de 2017 (mais de mil proposições), foi possível classificá-las por mandato presidencial ou outro período de interesse. Para separar as mensagens por tema, empregou-se a pesquisa documental.

\subsection{PROBLEMA DE PESQUISA}

$\mathrm{O}$ processo legislativo dos acordos internacionais assemelha-se às demais tramitações legislativas em certos aspectos. Porém, possui especificidades que compensam o esforço investigatório. Em um estudo minucioso sobre a produção legislativa, Fábio de Barros Correia Gomes (2013, p. 59) destaca que, sobre os decretos legislativos (tanto os que abordam tratados internacionais quanto os que sustam atos normativos do Executivo), "essas proposições [...] são numerosas e seguem tramitação diferenciada, de modo que necessitariam de estudos específicos." O que nos instiga é procurar representar a relação entre os poderes Legislativo e Executivo, por intermédio dos números extraídos do processo de elaboração dos acordos, apesar de existirem várias questões intermediárias que norteiam este trabalho. Há indicativos iniciais de que os tratados levam tempo considerável para sua aprovação possivelmente, mais tempo na Câmara do que no Senado. Há acordos que não são enviados ao Congresso? O Executivo promulga todos os acordos aprovados pelo Congresso? Matérias

\footnotetext{
${ }^{8}$ Os parâmetros empregados no Sistema de Informação Legislativa (Sileg) foram os seguintes: Tipo/Subtipo da Proposição: MSC (Mensagem); MMP (Mensagem do Ministério Público da União); MSC (Mensagem de Acordos e outros). Data da apresentação: de 5 de outubro de 1988 a 9 de maio de 2017. Ementa: que contenha "convenção", "acordo" ou "ato internacional". Explicacao da ementa: que contenha "convenção", "acordo" ou "ato internacional”. Indexação: que contenha "convenção", "acordo" ou "ato internacional".
} 
SILVA, R. Q; REGES, C. P. C. Acordo internacional: a relação entre legislativo e executivo traduzida em números

influenciam realmente no tempo de tramitação? A Comissão de Representação do Parlamento do Mercosul impôs um ritmo mais acelerado?

Antes de adentrar a relação entre os poderes, é preciso estabelecer o conceito de “tratado internacional”, este importante instrumento da política externa.

\section{A DEFINIÇÃO DE “TRATADO INTERNACIONAL”}

O "tratado" é um acordo firmado entre Estados soberanos ou Entidades Internacionais, que se submetem a determinadas regras a fim de alcançarem seus objetivos. Na definição exposta por José Francisco Rezek (2010, p. 14), "tratado é o acordo formal, concluído entre sujeitos de direito internacional público, e destinado a produzir efeitos

jurídicos". Hildebrando Accioly (1995, p. 120) ensina que "os tratados são considerados uma das fontes do Direito Internacional positivo e são conceituados como todo acordo formal, firmado entre pessoas jurídicas de Direito Internacional Público, tendo por finalidade a produção de efeitos jurídicos."

Nos termos da Convenção de Viena de 1969 (Brasil, 2009), “tratado” significa um acordo internacional concluído por escrito entre Estados e regido pelo Direito Internacional, quer conste de um instrumento único, quer de dois ou mais instrumentos conexos, qualquer que seja sua denominação específica.

Há muitas variações nominais na história evolutiva dos tratados, sendo que as mais recorrentes na pesquisa realizada foram "tratado", "acordo", "acordo-quadro", "pacto", "convenção", "protocolo" e "memorando de entendimento".

De fato, o tratado internacional é cercado de muita simplicidade diante dos diversos detalhes que envolvem sua construção. Nessa perspectiva, os tratados modificam de maneira profunda a vida, a liberdade, os direitos e os deveres de pessoas comuns, ao estabelecerem, entre outros comandos, (1) um conjunto de direitos e garantias fundamentais (diversos tratados de direitos humanos); (2) um conjunto de regras comerciais em escala global e regional - acordos constitutivos da Organização Mundial do Comércio (OMC); (3) o desenvolvimento sustentável dos Estados (tratados em matéria ambiental); (4) a viabilidade de blocos de objetivos comuns (a exemplo do Mercosul e da União Europeia); e (5), por último, a promoção da paz e o controle das armas (acordos nucleares).

Com dados tirados de uma pesquisa na base de dados de atos do Ministério das Relações Exteriores (MRE), visualiza-se, na Figura 1, a quantidade de acordos firmados em 
pouco mais de cem anos, abarcando-se todos os atos, inclusive os acordos executivos, que não são submetidos ao crivo do Congresso Nacional. O volume de atos internacionais celebrados constitui-se, portanto, em um dos indicadores mais objetivos e eloquentes da atividade diplomática (BRASIL, 2010, p. 3). Os tratados são cada vez mais frequentes em um mundo globalizado, em que avulta a cooperação entre Estados - cooperação esta que se efetiva nos mais variados quadrantes do direito (RODAS, 2015; OLIVEIRA, 2011).

FIGURA 1 - ATOS CELEBRADOS DE 1911 A 2017

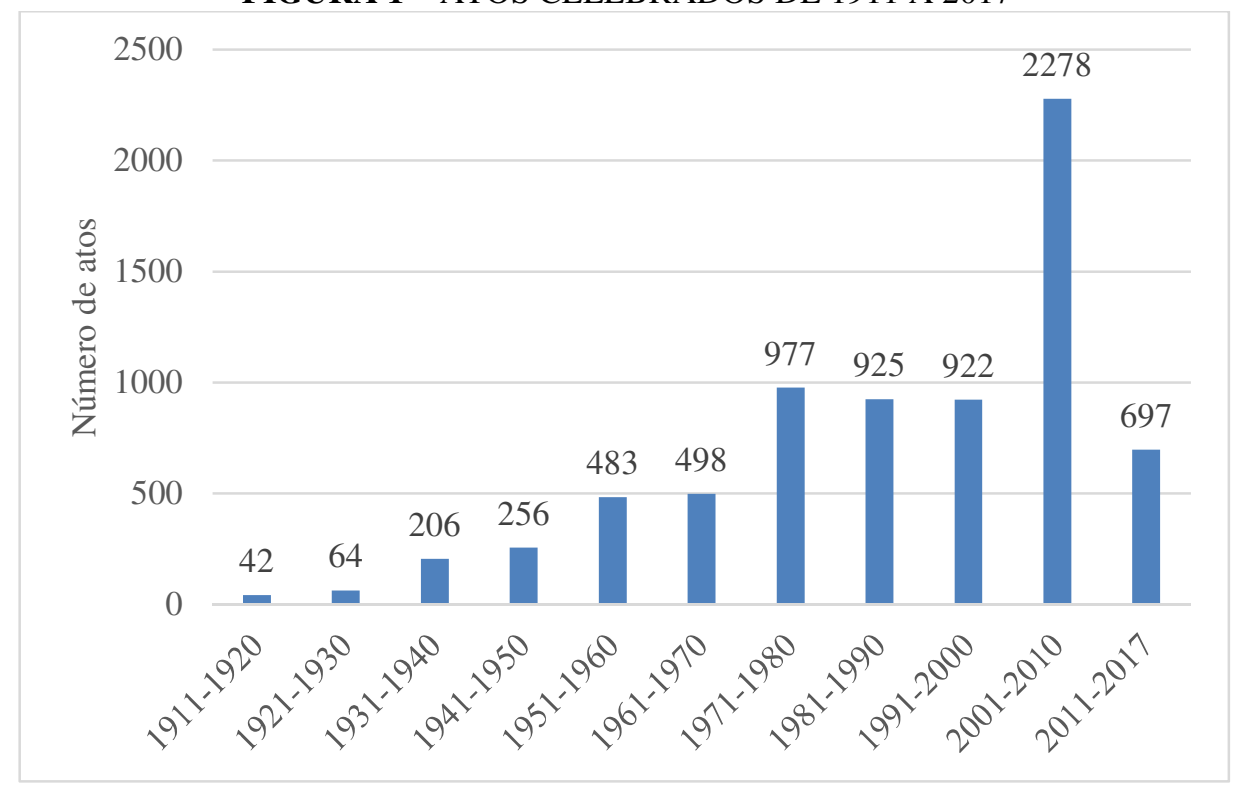

FONTE: O autor (2017).

Somando-se todos os atos do período demonstrado, de 1911 até 9 de maio de 2017, obtêm-se 7348 instrumentos de acordo. Vale lembrar que nem todos são enviados ao Congresso Nacional (verificar item 5.1).

É notável a diversidade de temas enfrentados pelos tratados internacionais. Na base de dados do Itamaraty, encontra-se cerca de duzentos tipos de assuntos possíveis, e tal variedade temática reflete as mudanças estruturais no Direito Internacional (CAVACANTI JÚNIOR, 2015, p. 14). Tal fato foi identificado na pesquisa ao se classificar os acordos em vinte temas, os quais influenciam na quantidade de comissões temáticas constantes do despacho de distribuição da mensagem pelo Presidente da Câmara, podendo resultar na criação de apenas uma comissão especial, quando houver a necessidade de análise técnica por mais de três órgãos colegiados.

O acordo não nasce de forma unilateral, surgindo da atuação de dois poderes, conforme se expõe a seguir. 
SILVA, R. Q; REGES, C. P. C. Acordo internacional: a relação entre legislativo e executivo traduzida em números

\section{A RELAÇÃO ENTRE OS PODERES EXECUTIVO E LEGISLATIVO}

Ao longo da história, diversos autores abordaram a Tripartição dos Poderes (separação de governo em três), sendo Aristóteles pioneiro no que diz respeito a essa questão, em sua obra "A Política", que contempla a existência de três órgãos separados aos quais caberiam as decisões de Estado - sendo eles o Poder Deliberativo, o Poder Executivo e o Poder Judiciário. Em seguida, Montesquieu definiu a tripartição e as devidas atribuições do modelo mais aceito atualmente: o Poder Legislativo, que elabora as leis; o Executivo, que se ocupa de implantá-las e dar-lhes execução; e o Judiciário, que é o responsável pela ordem jurídica, ou seja, pela interpretação das normas, conjugando-as ao caso concreto.

As constituições brasileiras republicanas nunca se ativeram muito ao relacionamento entre os poderes no que tange aos tratados. Luiz Gustavo Cavalcanti Junior (2015, p. 31) comparou todas elas, com exceção da Carta de 1937, evidenciando a necessidade de colaboração entre o Poder Executivo e o Poder Legislativo na conclusão dos tratados internacionais, já que as Cartas Políticas deixaram lacunas e uma atmosfera de obscurantismo a esse respeito (RODAS, 2015; MAZZUOLI, 2001, p. 43).

Mariana Chaimovich (2017, p. 39) alinha-se a essa teoria, afirmando que "a interação entre o Congresso Nacional e o Poder Executivo no processo de internalização de tratados, especificamente na Figura do MRE, principal formulador da política externa brasileira, não é clara." Na realidade, a Constituição Federal dedicou-se de maneira tímida ao Direito Internacional. São poucos os artigos a esse respeito, e mesmo esses poucos trazem dúvidas quanto à sua interpretação, apesar de o tema ter sido objeto de intensos e longos debates durante a constituinte de 1987-1988 (BRASIL, 2009, p. 3).

Apesar da insuficiência normativa acerca dos tratados, os poderes, fundamentados na independência e harmonia, instituíram um processo peculiar para que se tornasse possível a lida com eles, por meio do qual se identifica a cooperação entre tais instâncias na feitura de um ato complexo. Dito de outra forma, o tratado surge da atuação colaborativa entre dois poderes - a denominada "conjugação de duas vontades homogêneas", segundo o ministro Celso de Mello, do STF (BRASIL, 2001). De um lado, o Executivo tem a prerrogativa de dar início às tratativas e confeccionar o texto juntamente com os demais partícipes. De outro, o Poder Legislativo atua no plano interno em prol do interesse dos cidadãos para aperfeiçoar os termos postos. 
Para tanto, parafraseando o ilustre Rui Barbosa, a pátria não é somente o Presidente da República ou seu delegatário: “A pátria não é ninguém: são todos” (BARBOSA, 1903, p. 360). Desse modo, observa-se que a participação congressual não se restringe à função tradicional de fiscalização dos atos do Executivo: indo além dela, atua na formação do ato, com debates e possíveis modificações ${ }^{9}$. Stefanie Tomé Schmitt (2011, p. 99), ao analisar os trabalhos da Comissão de Relações Exteriores e Defesa Nacional (CRE) do Senado Federal, conclui:

\begin{abstract}
Importa destacar que a postura dos parlamentares brasileiros, que integram a Comissão no período estudado, não foi desinteressada. Houve uma participação ativa de, pelo menos, 129 legisladores, os quais fizeram uso dos mecanismos político-institucionais existentes para ter consideradas suas preferências e, assim, influenciar a formulação da política externa brasileira. Os Senadores tanto tornaram público valores e interesses presentes na sociedade brasileira, colocando em vigor uma espécie de diplomacia parlamentar, quanto fiscalizaram o trabalho do Executivo.
\end{abstract}

De fato, os dois poderes se agrupam com o propósito de materializar um ato que, se agindo isoladamente, o Executivo ou o Legislativo não conseguiriam colocar em prática. Percebe-se, dessa forma, a separação dos poderes idealizada por Montesquieu em plena aplicação.

Efetivamente, a Constituição de 1988 perdeu a oportunidade de versar de forma moderna e clara a respeito da competência para celebrar tratados, ampliando ainda mais as divergências sobre o tema (CACHAPUZ DE MEDEIROS, 2008, p. 116). Todavia, não se deve concluir que, nessa relação, o Poder Legislativo cumpre papel passivo e inerte: pelo contrário, sem ele o acordo não subsistiria — ou seja, não haveria acordo.

O processo de formação do tratado internacional intercala a atuação dos poderes Executivo e Legislativo. Antes de ser enviado ao Congresso Nacional, há um esforço dos atores no plano internacional no que diz respeito a inúmeras negociações com Estados em grandes conferências e mesas bilaterais ou multilaterais. Por força do art. 21 combinado com o art. 84 da Constituição Federal, cabe, respectivamente, à União manter as relações com Estados estrangeiros e ao Presidente da República celebrar os tratados.

O processo dos acordos pode ser dividido em uma fase externa e uma interna. A primeira pode ser dividida em: a) negociação; b) adoção; c) autenticação; d) assinatura; e e) ratificação. Já a segunda se divide em: a) fase congressual (Câmara dos Deputados e Senado

\footnotetext{
${ }^{9}$ As alterações também são motivo de controvérsias. O Senado prevê a possibilidade de emenda ao Projeto de Decreto Legislativo, e não ao texto do acordo. Na Câmara, o assunto consta em consultas feitas à CCJC (a exemplo da Consulta $\left.{ }^{\circ} 4,2004\right)$. Ainda sobre o tema, ver Lynch (2009).
} 
SILVA, R. Q; REGES, C. P. C. Acordo internacional: a relação entre legislativo e executivo traduzida em números

Federal); e b) após a ratificação, a promulgação e a publicação. Não se pretende detalhar cada uma dessas etapas neste texto.

De 1988 até 2001, o regime de tramitação fixado para as mensagens que encaminhavam acordos era ordinário e estendia-se aos projetos de decretos legislativos. A partir de 2002, o regime da mensagem passou a ser prioridade, de forma que os projetos passaram a receber a classificação de urgência. Ainda, o acordo em pleno vigor pode sofrer um revés, denominado "denúncia”, que significaria a saída do Brasil do acordo, adotada de forma unilateral pelo Poder Executivo do país - importa, aqui, realçar que tal saída se daria sem o consentimento do Legislativo (ver item 5.2). Nesse processo de construção do acordo, vale destacar a criação da Comissão do Mercosul, que trouxe ganhos em celeridade.

\section{REPRESENTAÇÃo BRASILEIRA NO PARLAMENTO DO MERCOSUl (CPCMS)}

A Representação Brasileira no Parlamento do Mercosul, órgão de ligação entre o Congresso Nacional e o Parlamento do Mercosul, é uma Comissão Mista, formada por deputados e senadores. A comissão segue regras próprias estabelecidas pelo Protocolo Constitutivo do Parlamento do Mercosul, adicional ao Tratado de Assunção. Para promover maior celeridade aos processos relacionados às normas do Mercosul no ordenamento jurídico de cada país que necessite de aprovação parlamentar, faz-se necessário, antes de mais nada, o estabelecimento claro dos fluxos de informação a esse respeito, especialmente entre os órgãos decisores e os Parlamentos (MARIANO, 2015, p. 150). Conforme estabelece o artigo $4^{\circ}$, inciso 12, do Protocolo Constitutivo do Parlamento do Mercosul, caso sigam o procedimento preferencial, as normas serão apreciadas apenas pela Representação Brasileira e pelos plenários da Câmara dos Deputados e do Senado Federal. Se o projeto de norma do Mercosul for aprovado pelo órgão decisório, de acordo com os termos do parecer do Parlamento, a norma deverá ser enviada pelo Poder Executivo nacional ao seu respectivo Parlamento, dentro do prazo de quarenta e cinco (45) dias, contados a partir da sua aprovação.

Os Parlamentos nacionais, segundo os procedimentos internos correspondentes, deverão adotar as medidas necessárias para a instrumentalização ou criação de procedimentos preferenciais para a consideração das normas do Mercosul que tenham sido adotadas de acordo com os termos do parecer do Parlamento. O prazo máximo de duração do procedimento previsto não deve exceder cento e oitenta (180) dias corridos, contados a partir 
do ingresso da norma no respectivo Parlamento nacional. Se, dentro do prazo desse procedimento preferencial, o Parlamento do Estado Parte não aprovar a norma, esta deverá ser reenviada ao Poder Executivo para que a encaminhe à reconsideração do órgão correspondente do Mercosul.

Concluída a apreciação da matéria pela Representação Brasileira, o parecer e o respectivo projeto de decreto legislativo deverão ser devolvidos à Mesa da Câmara dos Deputados para numeração e inclusão na Ordem do Dia daquela Casa. A apreciação da matéria no plenário de cada uma das Casas obedecerá às respectivas disposições regimentais. Não se tem notícia da implantação desse mecanismo de aceleração do trâmite das matérias nos Legislativos dos países integrantes do Mercosul. Porém, a criação por si só da Comissão do Mercosul, contendo membros das duas Casas Legislativas, voltada para os temas da região, resultou em benefícios ao processo legislativo, como será demonstrado no item 5.7.

\section{A RELAÇÃO ENTRE OS PODERES LEGISLATIVO E EXECUTIVO EM NÚMEROS}

Após a aplicação dos procedimentos de pesquisa, identificaram-se os resultados que serão apresentados na sequência.

\subsection{ACORDOS QUE NÃO PASSAM PELO CRIVO DO PARLAMENTO}

De início, como mencionado, existem acordos que não são enviados ao Congresso Nacional. Segundo o MRE, são instrumentos simplificados, que envolvem atos da diplomacia ordinária e complementares (BRASIL, 2010, p. 8). O objetivo desses acordos é dar maior dinamismo às relações internacionais, não obstante serem motivo de controvérsia, existindo posicionamentos favoráveis ao seu envio ao referendo congressual. Os acordos de forma simplificada, exarados pelo presidente, são iguais, em autoridade, aos tratados, apesar de não serem submetidos a nenhuma espécie de controle constitucional (RODAS, 1973, p. 321).

Cachapuz de Medeiros (2008, p. 101), ao citar as doutrinas favoráveis e contrárias a essa prática, realça as palavras de Rezek acerca da Subcomissão da Nacionalidade, da Soberania e das Relações Internacionais nos debates desenvolvidos na Constituinte em 1988: "a regra segundo a qual o controle congressional dos compromissos externos da República é um controle total, é um controle que não comporta evasões." 
SILVA, R. Q; REGES, C. P. C. Acordo internacional: a relação entre legislativo e executivo traduzida em números

Sob a atual Constituição Federal, foram celebrados 4316 atos, sendo que os mandatos do ex-presidente Lula se destacaram em volume de celebrações, totalizando mais de 2000 atos, conforme se vê na Figura 2.

FIGURA 2 - ATOS CELEBRADOS DE 1988 A 2017

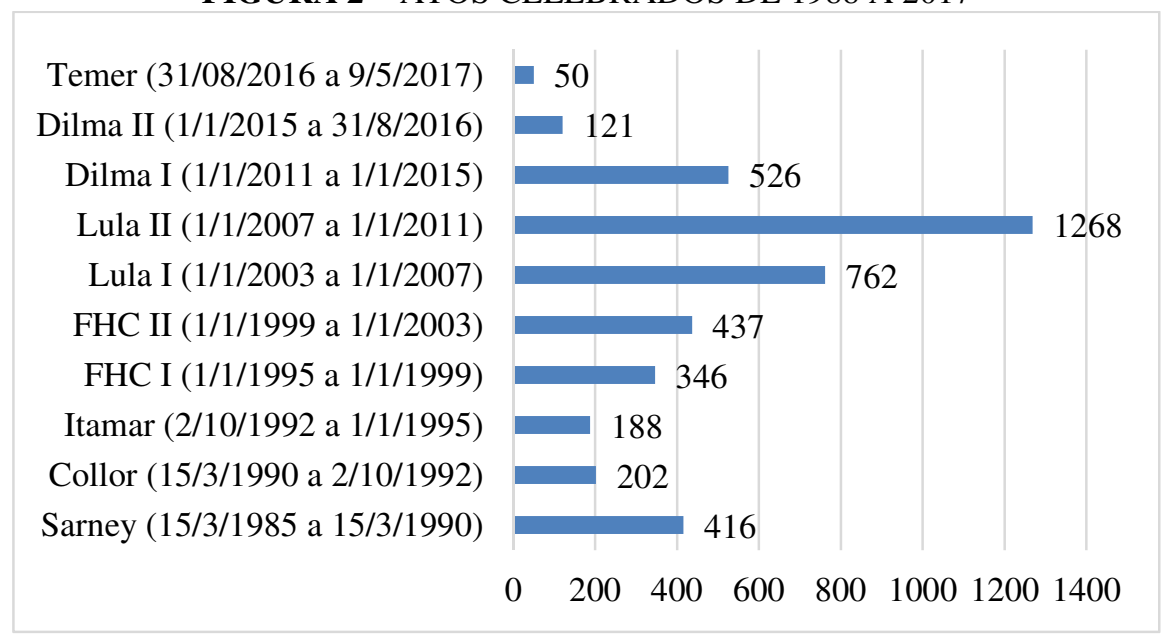

FONTE: O autor (2017).

$\mathrm{Na}$ sequência, consideram-se as mensagens enviadas ao Parlamento no período de 1988 a 9 de maio de 2017, as quais totalizaram 1375 itens. As mensagens do presidente são compostas do texto do acordo, de uma exposição de motivo e de um aviso.

FIGURA 3 - ATOS ENVIADOS AO CONGRESSO DE 1988 A 2017

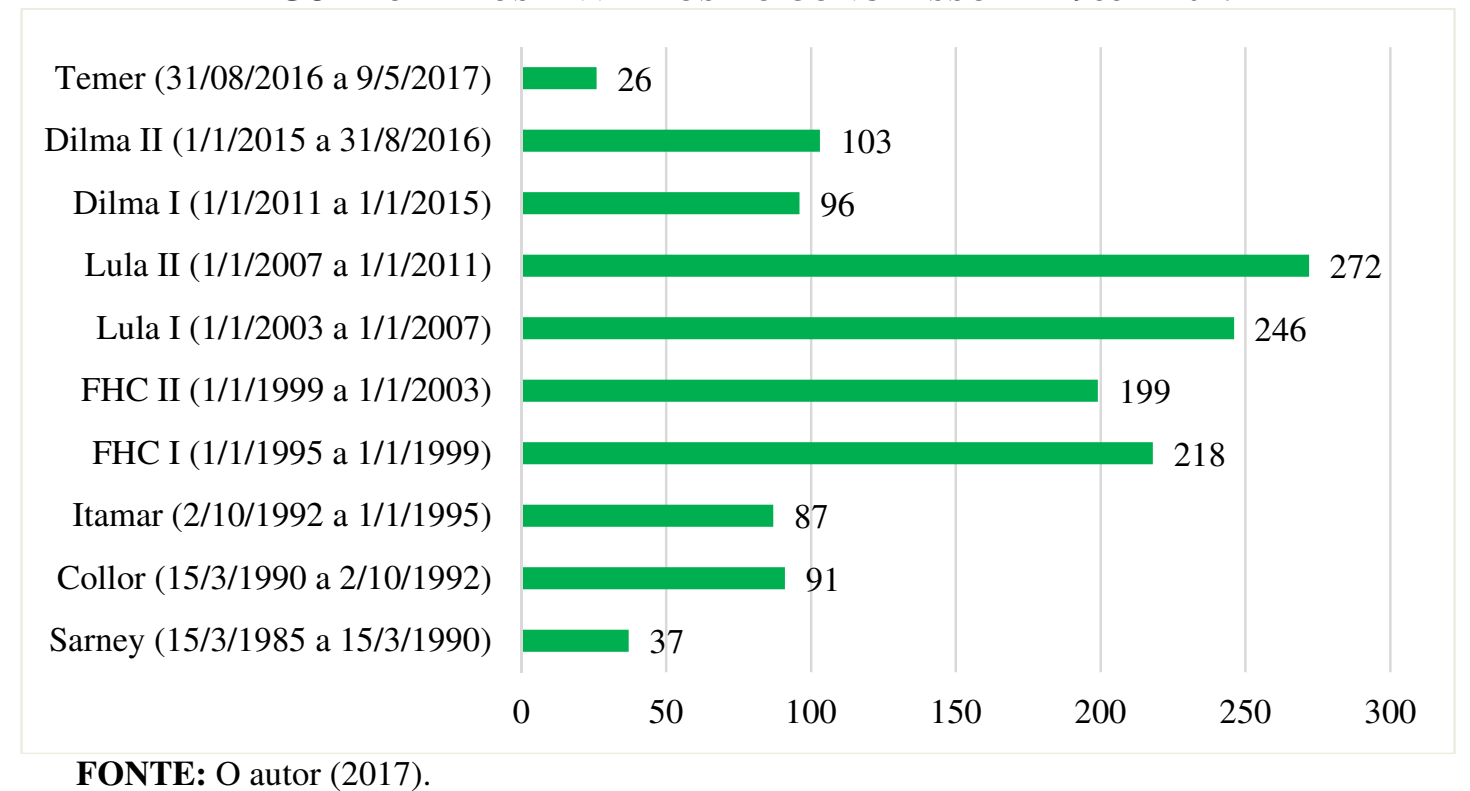

Assim, ao se comparar a Figura 2 com a Figura 3, nota-se que, apesar da discricionariedade do Poder Executivo de enviar ou não um acordo assinado, pouco mais de 
trinta por cento dos atos celebrados no período foram submetidos ao Congresso Nacional. Não é objeto desta pesquisa a investigação dos motivos que levaram um ou outro presidente a assinar mais ou menos acordos ou a deixar de encaminhá-los ao Congresso. Assim, é recomendável que estudos futuros procurem respostas a essas questões.

Por hora, resta-nos, em razão da baixa taxa de envio de acordos ao Congresso, propor o estabelecimento de uma comunicação formal, de natureza executiva, entre os poderes, para tratar dos atos celebrados que não foram enviados, em benefício da transparência e da relação harmoniosa entre os poderes.

\subsection{A “REVOGAÇÃO” DE ACORDOS DE FORMA UNILATERAL}

A “denúncia” é considerada uma forma de extinção. Por meio dela, uma das partes contratantes declara, unilateralmente, sua vontade de abandonar o tratado, extinguindo, desse modo, seus direitos e suas obrigações diante dos termos assumidos inicialmente nas negociações. Cabe salientar que a revogação, chamada de "denúncia", não é cabível em todos os casos, mas apenas quando há previsão de denúncia no contrato inicial. Além disso, nos acordos multilaterais, o tratado não se extingue, permanecendo no que diz respeito aos demais partícipes. Em pesquisa no banco de dados do Itamaraty, em 2 de setembro de 2017, identificaram-se 203 (duzentos e três) acordos internacionais na situação de denunciados.

A apreciação das normas constitucionais brasileiras a respeito da ratificação e da denúncia dos tratados internacionais demonstra que há vários pontos que carecem de uma regulamentação mais clara nesse sentido (NUNES, 2010, p. 131; JARDIM, 2010). Segundo Mazzuoli (2015, p. 1), a questão é discutida há décadas, e o "Supremo Tribunal Federal está em vias de decidir" que atitude tomar a esse respeito, por intermédio da Ação Direta de Inconstitucionalidade (ADI) 1.625. Nesse processo, a Confederação Nacional dos Trabalhadores na Agricultura (CONTAG) e a Central Única dos Trabalhadores (CUT) ingressaram no STF com uma ADI visando a inconstitucionalidade do Decreto $\mathrm{n}^{\circ} 2.100$, de 20 de dezembro de 1996, que denunciou a Convenção 158 da Organização Internacional do Trabalho, devidamente aprovada pelo Congresso Nacional (Decreto Legislativo $n^{\circ}$ 68/92) e promulgada pelo Poder Executivo (Decreto n 1.855/96). Até aquela data, tal Convenção estava em vigor no Brasil.

O jurista Clóvis Beviláqua, consultor do Itamaraty de 1906 a 1934, chamado a se pronunciar acerca do tema, em parecer de 5 de julho de 1926, afirmou entender ser possível que o Poder Executivo denunciasse tratados sem o assentimento do Parlamento, ainda que 
SILVA, R. Q; REGES, C. P. C. Acordo internacional: a relação entre legislativo e executivo traduzida em números

aquele tenha necessitado da vontade deste último quando da ratificação do acordo (CACHAPUZ DE MEDEIROS, 2000, p. 347). Em posição diversa, Miranda (2015, p. 351357) entende não ser possível a denúncia de tratados pelo Poder Executivo sem autorização do Parlamento, pois tal atitude violaria o texto constitucional em seus princípios.

Em uma busca no site do Planalto, verificou-se que a última denúncia realizada ocorreu em 24 de julho de 2015, nos seguintes termos:

\begin{abstract}
DECRETA:
Art. 1ำ Deixa de vigorar para a República Federativa do Brasil, a partir de 16 de julho de 2016, o Tratado entre a República Federativa do Brasil e a Ucrânia sobre Cooperação de Longo Prazo na Utilização do Veículo de Lançamentos Cyclone-4 no Centro de Lançamento de Alcântara, firmado em Brasília, em 21 de outubro de 2003.

Art. 2o Fica revogado o Decreto n- 5.436 , de 28 de abril de 2005, a partir de 16 de julho de 2016.

Art. 3- Este Decreto entra em vigor na data de sua publicação.

Por intermédio de um decreto, a Presidente revogou o decreto promulgador do tratado, que deixa de vigorar no plano interno. De acordo com a posição exposta de que os acordos são fruto da vontade de dois Poderes, consequência de uma relação exercida sob os princípios da tripartição. Depreende-se que seu desfazimento exige os cuidados e a atenção de ambos os Poderes.

O Congresso Nacional tem como encargo a elaboração de leis que assegurem o funcionamento do sistema jurídico e consequentemente a pacificação social. Contudo, sua participação no instituto da denúncia não é uma faculdade, mas sim um dever, que, ao ser violado fere diretamente a Constituição da República. (BRASIL, 2015).
\end{abstract}

Portanto, é razoável acreditar no surgimento de mais uma etapa no peculiar processo de tramitação dos tratados, considerando-se a atuação dos poderes na apreciação da saída do Brasil de um determinado acordo (denúncia), por causa dos desdobramentos da ADI 1.625.

\title{
5.3 A MÉDIA DE TEMPO DE TRAMITAÇÃO
}

Buscou-se uma resposta à questão de quanto tempo, em média, leva-se para se construir um acordo internacional. Na Tabela 1, visualizam-se cada um desses períodos, salvo o intervalo entre a assinatura do acordo e seu encaminhamento ao Congresso Nacional. Assim, ao intervalo da entrega da mensagem até seu envio ao Senado, chamamos "tempo na Câmara dos Deputados" (Tcd); à deliberação no próprio Senado, "tempo no Senado Federal" (Tsf); e, ao tempo entre a promulgação pelo Congresso Nacional e a promulgação pelo Poder Executivo, "tempo no Poder Executivo" (Tpe). Encontrou-se, ainda, o tempo de apreciação no âmbito da Comissão de Relações Exteriores e Defesa Nacional da Câmara para a confecção do Projeto de Decreto Legislativo (PDC), o qual representaremos pela sigla "Tpdc". É 
possível, também, analisar o tempo que o processo passa no Congresso Nacional (ou seja, no Poder Legislativo) a partir da soma dos tempos utilizados pelas duas Casas, o qual representaremos pela sigla "Tcn". Elaboraram-se duas médias, a "simples" e a "sem outliers", com o emprego de técnicas estatísticas para suprimir os tempos demasiadamente elevados ${ }^{10}$.

TABELA 1 - TEMPO DE TRAMITAÇÃO

\begin{tabular}{|c|c|c|}
\hline Tramitação & Média (dias) & $\begin{array}{c}\text { Média sem outliers } \\
\text { (dias) }\end{array}$ \\
\hline Tramitação para PDC (Tpdc) & 200 & 168 \\
\hline Tramitação na CD (Tcd) & 567 & 506 \\
\hline Tramitação no SF (Tsf) & 143 & 117 \\
\hline Tramitação no CN (Tcn) & 710 & 623 \\
\hline $\begin{array}{c}\text { Tramitação com o Poder } \\
\text { Executivo (Tpe) }\end{array}$ & 450 & 323 \\
\hline
\end{tabular}

FONTE: O autor (2017).

Percebe-se que o tempo na Câmara dos Deputados é realmente o mais extenso (quase quatro vezes o do Senado) e que, sem outliers, ultrapassa o Senado em quatro vezes. Já o Poder Executivo leva mais da metade do tempo do Congresso Nacional na tramitação. Porém, isso corresponde apenas ao tempo para promulgação do acordo, além de não ter feito parte da pesquisa o período entre a assinatura e o envio ao Parlamento - o que, certamente, se fosse somado, aumentaria muito o número de dias em que o acordo fica sob a guarda do Poder Executivo, conforme relata Rodrigo D'Araujo Gabsch (2010, p. 204-206).

Assim, a afirmação de que o processo no Congresso é lento, comparando-se ao tempo demandado pelo Executivo, é confirmada, mas sem que se inclua a fase inicial do processo - a qual, em razão de cumprimento de etapas, segundo Gabsch (2010), tem onerado em muito a dinâmica dos acordos.

Na Tabela 2, utilizam-se os dias de tramitação da Mensagem n ${ }^{\circ} 193$, de 2015, com o propósito de se comparar seus dados com as médias da Tabela 1.

TABELA 2 - TEMPO DE TRAMITAÇÃO DA MENSAGEM Nº 193, DE 2015

\begin{tabular}{|c|c|}
\hline Tramitação & Dias \\
\hline Tramitação para PDC (Tpdc) & 65 \\
\hline Tramitação na CD (Tcd) & 540 \\
\hline Tramitação no SF (Tsf) & 16 \\
\hline Tramitação do CN (Tcn) & 556 \\
\hline $\begin{array}{c}\text { Tramitação Poder Executivo } \\
\text { (Tpe) }\end{array}$ & 251 \\
\hline
\end{tabular}

FONTE: O autor (2017).

\footnotetext{
10 A retirada dos outliers se deu em relação a tempos de processo considerados "anormais" e extremos. Para tanto, utilizou-se a tabela de Thompson modificada.
} 
SILVA, R. Q; REGES, C. P. C. Acordo internacional: a relação entre legislativo e executivo traduzida em números

Nota-se que a mensagem concluiu seu processo de forma bastante efetiva, pois todos os tempos estão abaixo das médias simples. Quanto às médias livres de outliers, apenas seu tempo na Câmara dos Deputados (Tcd) a extrapolou, em poucos dias; porém, em compensação, no Senado Federal a matéria tramitou rapidamente em dezesseis dias. Portanto, tais dados são úteis para confrontos posteriores, para identificar onde a proposição enfrentou dificuldades para deliberação e para que se pensem estratégias prévias capazes de promover uma tramitação mais célere, sem que se desrespeitem as regras incidentes sobre o processo.

\subsection{VARIAÇÃO DO TEMPO DE TRAMITAÇÃO CONFORME O GRUPO TEMÁTICO}

Sobre o tempo de tramitação em relação ao grupo temático, empregaram-se as variáveis mencionadas anteriormente. Assim, concluiu-se que, de acordo com o tema do tratado, ele pode ter uma tramitação mais célere ou mais demorada. Em razão da extensão da tabela, em vez de demonstrar os vinte grupos utilizados na pesquisa, optou-se por seis exemplos, conforme a Figura 4:

FIGURA 4 - ACORDOS VERSUS TEMPO VERSUS TEMA

\begin{tabular}{|c|c|c|c|c|c|c|}
\hline \multirow{6}{*}{ 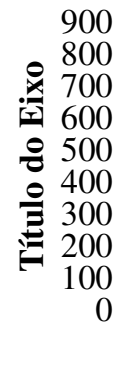 } & & & & & & \\
\hline & & & & & & \\
\hline & & & & & & \\
\hline & & & & & & \\
\hline & & & & & & \\
\hline & Previdência & Defesa & Cultura & $\begin{array}{c}\text { Cooperação } \\
\text { Técnica }\end{array}$ & Direito & $\begin{array}{l}\text { Seguridade } \\
\text { Social }\end{array}$ \\
\hline$\square$ Tpdc & 140 & 164 & 152 & 187 & 248 & 191 \\
\hline Tcd & 362 & 455 & 480 & 638 & 683 & 779 \\
\hline Tsf & 90 & 93 & 150 & 110 & 201 & 158 \\
\hline Tpe & 225 & 655 & 352 & 445 & 461 & 492 \\
\hline
\end{tabular}

FONTE: O autor (2017).

Conforme mencionado, durante a pesquisa classificaram-se os tratados em vinte grupos temáticos, sendo um deles mais genérico ("cooperação técnica”). Na Figura 4, apresentaram-se apenas seis grupos capazes de demonstrar a variação do tempo em função do grupo. Ao se confrontar com as médias da Tabela 1, constata-se que o item "Seguridade Social" ultrapassa em mais de cinquenta por cento o tempo médio. 
Outro aspecto digno de observação é a necessidade de aperfeiçoamento na classificação temática, para que se evidencie na ementa da mensagem enviada ao Congresso Nacional o principal conteúdo do tratado, facilitando-se assim sua identificação. Em razão dessa ausência de clareza, optou-se, durante a pesquisa, pelo agrupamento sob a denominação "cooperação técnica" das mensagens que não favoreciam sua própria identificação.

Ao cruzar os dados desde a apresentação da mensagem até a promulgação do Decreto Legislativo, observa-se que o tema da mensagem influenciou no tempo de sua tramitação, variando também a depender da Casa Legislativa. Portanto, o fato de o item "Seguridade Social" demandar maior quantidade de dias na Câmara dos Deputados não faz com que exija mais tempo no Senado e vice-versa.

\subsection{O TEMPO DE TRAMITAÇÃO DO PROJETO DE DECRETO LEGISLATIVO (PDC)}

Ao utilizar os grupos temáticos e confrontá-los com o tempo para elaboração do Projeto de Decreto Legislativo (Tpdc), verificou-se que há também variação a depender do conteúdo da mensagem. Descobriu-se que a confecção do PDC (Tpdc) consome de trinta a quarenta por cento do tempo de tramitação na Câmara dos Deputados (Tcd). A Tabela 1 mostra que se utiliza em média 200 dias para sua transformação em Projeto (Tpdc), e 567 dias para se encerrar o processo na Câmara dos Deputados (Tcd), o que perfaz 35\% do tempo (Tpdc/Tcd) - e, retirando-se os outliers, 33\%.

Dessa forma, o restante do tempo é dedicado às demais comissões e ao plenário, sendo que este último aprecia todos os acordos internacionais. Pode-se considerar que, apesar das votações no plenário ocorrerem de forma simbólica ${ }^{11}$, os acordos aguardam em uma "fila". Por isso, o restante do tempo (de sessenta a setenta por cento) pode estar, em grande parte, vinculado a esta espera para apreciação do plenário. Para que se chegue a essa conclusão efetivamente, será necessário aprofundar os estudos na existência ou não do congestionamento dos projetos no Plenário. A Figura 5 representa o Tpdc em relação ao Tcd, considerando-se tão-somente as seis áreas temáticas já mencionadas, da mesma forma que no item anterior, devido à extensão da tabela:

\footnotetext{
${ }^{11}$ A votação simbólica não exige o registro individual dos votantes, de acordo com o Art. 186 do Regimento Interno da Câmara dos Deputados (RICD).
} 
SILVA, R. Q; REGES, C. P. C. Acordo internacional: a relação entre legislativo e executivo traduzida em números

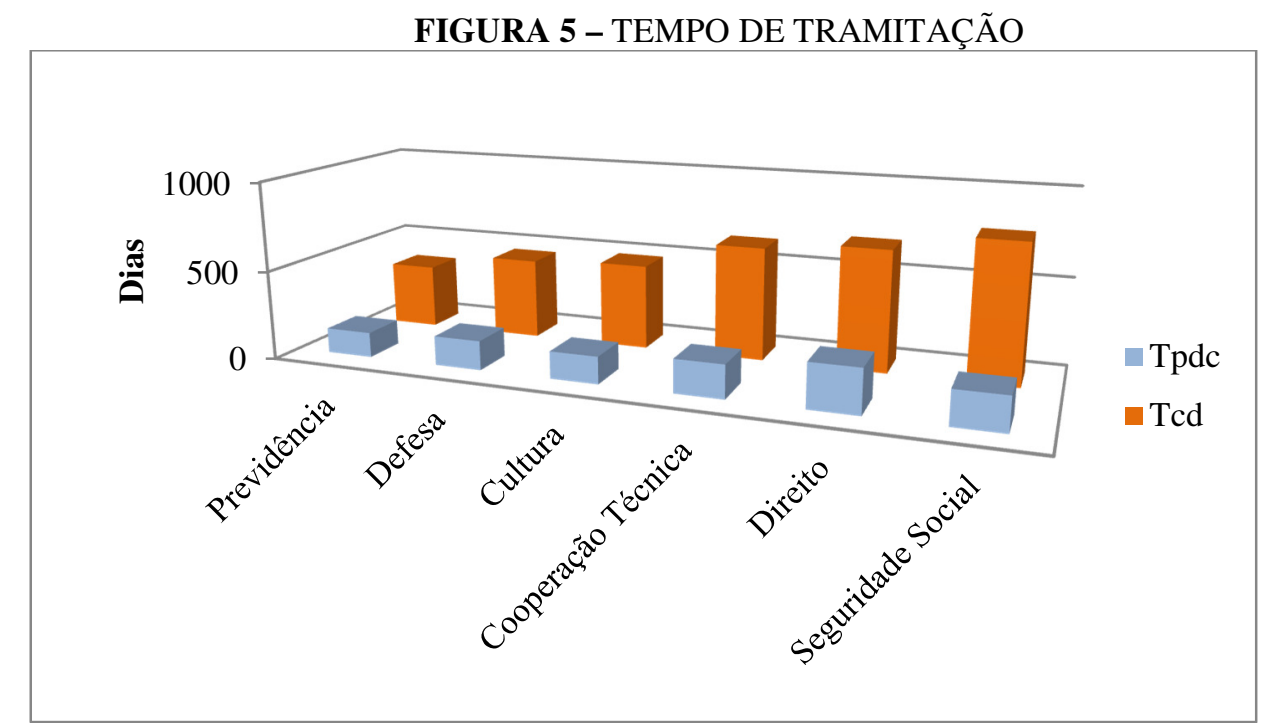

FONTE: O autor (2017).

Assim, a exigência de que os acordos passem pelo crivo do Plenário pode ser questionada, com o objetivo de se diminuir do número de dias para tramitação, considerandose que tal votação é simbólica. Talvez seja possível que o projeto encerre seu trâmite nas comissões, sendo levado ao Plenário apenas se necessário.

\subsection{A INFLUÊNCIA DO REGIME DE TRAMITAÇÃO}

Esperava-se que o tempo de tramitação fosse decrescente, seguindo-se a respectiva ordem: "ordinário", "prioridade" e "urgência". Na Câmara dos Deputados, o regime "urgente" dispensa exigências, interstícios e formalidades regimentais, além de sua matéria ser distribuída a todas as comissões ao mesmo tempo (art. 152 do RICD). Simone Diniz e Cláudio Ribeiro (2010, p. 81), por exemplo, avaliam a deliberação ocorrida na CREDN e afirmam que os parlamentares, em razão de tal regime, "dispuseram de um maior tempo para apreciação dos atos internacionais". Assim, conclui-se que tal regime deveria ser considerado. Em outro trecho dos mesmos autores, lê-se que "a determinação para que a maioria dos Atos Internacionais tramitasse em regime ordinário pode significar que o governo sabia que não enfrentaria problemas no âmbito da CRE” (RIBEIRO, 2010, p. 82), ficando novamente claro que os pesquisadores levaram em conta os tipos de regime ("ordinário", "prioridade" e "urgência").

Todavia, como apresenta a Figura 5, o regime de tramitação não produziu os efeitos desejados. Tal fato pode ter ocorrido em razão da quantidade excessiva de projetos em regime de urgência - não somente de acordos, mas de proposições em geral. Já no Senado Federal, 
o regime de tramitação refletiu exatamente o determinado inicialmente, conforme consta na Figura 6:

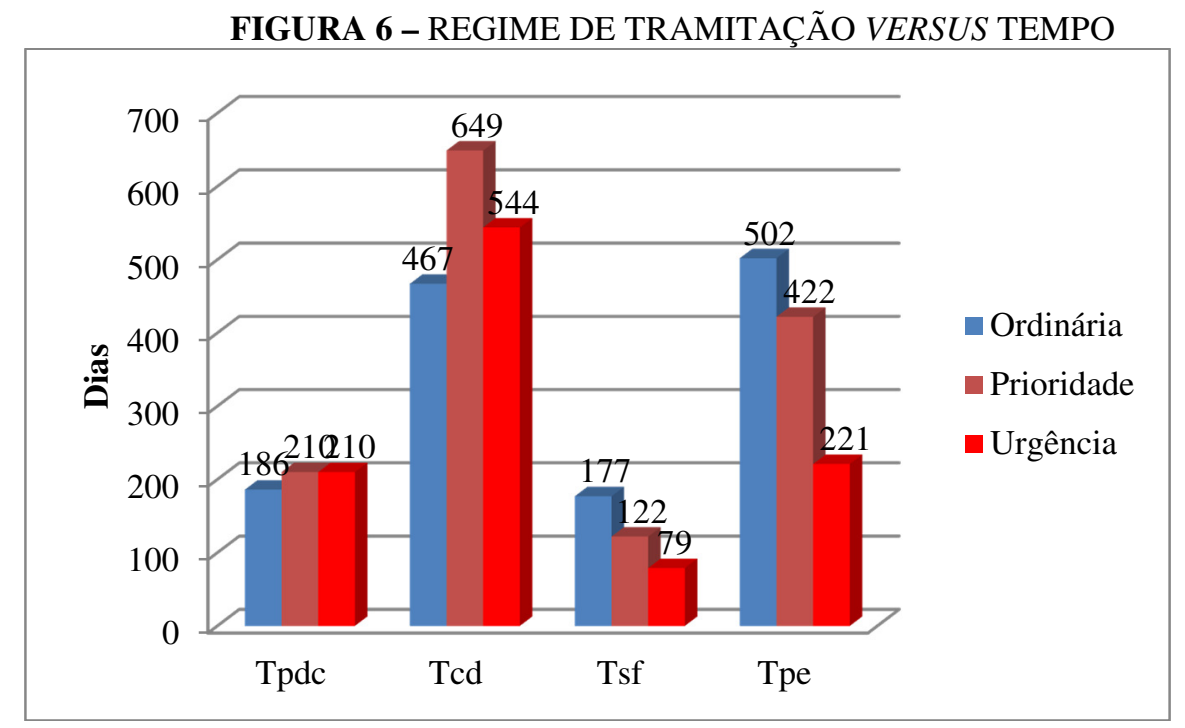

FONTE: O autor (2017).

Observou-se, ainda, que praticamente não há diferença relevante no lapso temporal de elaboração do PDC (Tpdc) no que diz respeito ao regime de tramitação. Isso ocorre pelo próprio funcionamento da Comissão de Relações Exteriores, responsável por praticamente todos os projetos de acordo internacional, em que o tempo de tramitação não faz diferença de acordo com a quantidade de processos.

Já na fase em que a mensagem tramita no Poder Executivo, apesar de este não estar submetido ao regime de tramitação instituído na fase congressual, há correspondência entre o tipo de regime e o tempo que tal mensagem leva para ser processada. Foram promulgados mais rapidamente aqueles que tramitaram em "urgência", seguidos por "prioridade" e, por último, pelos “ordinários”.

Portanto, a celeridade esperada não se concretizou na Câmara dos Deputados, pois tanto a elaboração do PDC quanto a sua apreciação não seguiram a regra pretendida, de acordo com a qual os processos classificados como "urgentes" concluiriam em menos dias sua tramitação.

\subsection{A CELERIDADE PROMOVIDA PELA COMISSÃO DO MERCOSUL}

Um outro ponto de destaque encontrado na pesquisa é a celeridade dada aos tratados que tramitaram inicialmente na Comissão de Representação Brasileira no Parlamento do 
SILVA, R. Q; REGES, C. P. C. Acordo internacional: a relação entre legislativo e executivo traduzida em números

Mercosul, quando esta passou a apresentar o Projeto de Decreto Legislativo. Criada em 2001, inicialmente essa comissão só apreciava a mensagem e a enviava para a Comissão de Relações Exteriores e Defesa Nacional (CREDN), para que esta apresentasse o PDC. Em 2006, a Comissão do Mercosul passou a propor o PDC e a enviá-lo para a CREDN. A partir daí, os projetos passaram a tramitar com uma celeridade maior, conforme se demonstrou na Figura 7:

FIGURA 7 - CREDN VERSUS MERCOSUL

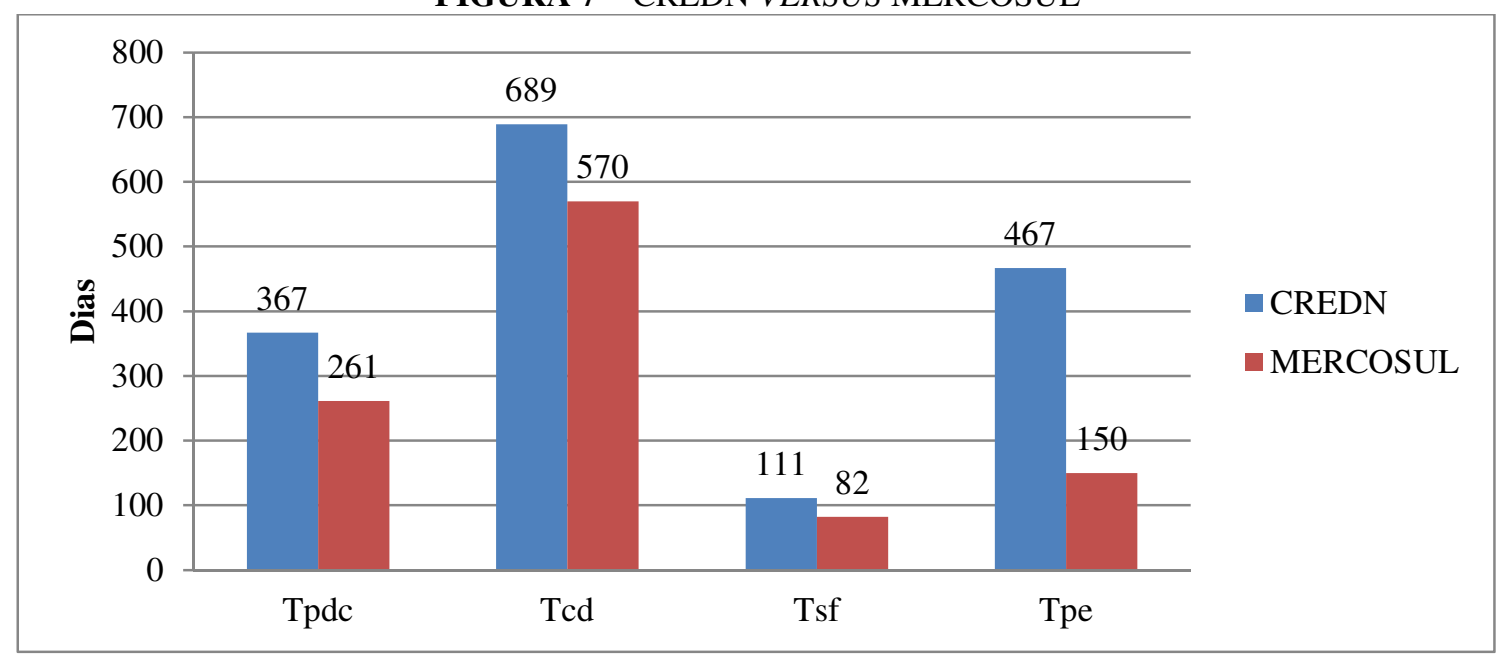

FONTE: O autor (2017).

Como se pode observar, houve uma economia de cerca de cem dias na Câmara dos Deputados e uma redução de um terço do tempo para que o Executivo publicasse o decreto promulgador. Tal fato configura-se em razão do princípio da especialização, uma vez que a Comissão do Mercosul é voltada para os assuntos do Mercosul e composta por parlamentares das duas Casas.

Dessa forma, a instituição da Comissão específica para tratar de assuntos relacionados ao Mercosul proporcionou maior ligeireza na apreciação dos acordos que por lá tramitaram.

\subsection{AS TAXAS DE APROVAÇÃO}

Por fim, analisou-se a Taxa de Apreciação (TA) na análise dos acordos pelo Congresso Nacional e, também, na tarefa a cargo do Poder Executivo. Esses dados mostraram que houve um grande sucesso na aprovação dos acordos internacionais pelo legislativo, 
superior à Taxa de Promulgação (TP) gerada pelo Executivo, mesmo tendo sido este o responsável pelo envio dos acordos.

TABELA 3 - TAXA DE APRECIAÇÃO (TA)

\begin{tabular}{|c|c|c|}
\hline Situação & Acordos & Índice \\
\hline Aprovados (DL) & 1182 & $86 \%$ \\
\hline Promulgados & 883 & $64 \%$ \\
\hline Sem promulgação & 296 & $22 \%$ \\
\hline Tramitando & 114 & $8 \%$ \\
\hline Retirado & 64 & $5 \%$ \\
\hline Apensado & 14 & $1 \%$ \\
\hline Rejeitado & 3 & $0 \%$ \\
\hline Prejudicado & 1 & $0 \%$ \\
\hline TOTAL & 1.375 & \\
\hline
\end{tabular}

FONTE: $\mathrm{O}$ autor (2017).

TABELA 4 - TAXA DE PROMULGAÇÃO (TP)

\begin{tabular}{|c|c|}
\hline Situação & Índice \\
\hline Promulgados & $75 \%$ \\
\hline Sem Promulgação & $25 \%$ \\
\hline
\end{tabular}

FONTE: $O$ autor (2017).

Verifica-se na Tabela 3 uma elevada taxa de aprovação dos acordos internacionais no Congresso Nacional, na ordem de $86 \%$. A partir da Tabela 4, nota-se que 25\% dos acordos aprovados no Congresso Nacional não foram promulgados pelo Poder Executivo. Nesse sentido, vale frisar que nem sempre a não promulgação se dá por inércia daquele poder, uma vez que, em atos multilaterais, é necessário que um mínimo de signatários faça seus respectivos depósitos.

Essa taxa de sucesso pode refletir o pensamento de cooperação explicado por Pedro Feliú e Janaina Onuki (2014, p. 86), que destacam a importância de "unidade no parlamento" para não se "corroer a credibilidade do país no âmbito externo", demonstrando-se que existe "um elevado grau de consenso nas decisões legislativas referentes à política externa".

Porém, ainda há uma quantidade elevada de atos não promulgados. Depois de todo o esforço legislativo empreendido na sua aprovação, como visto, somando-se o tempo no Congresso Nacional e no Executivo (Tcn + Tpe), são necessários, em média e sem outliers, 946 dias (ou seja, quase três anos) para se concluir o processo. Dessa forma, assim como se propôs em relação aos atos não enviados ao Congresso Nacional, caberia uma comunicação formal entre os poderes, a fim de que ambos se mantivessem informados a respeito da situação desses acordos em status de espera.

\section{CONCLUSÃO}


SILVA, R. Q; REGES, C. P. C. Acordo internacional: a relação entre legislativo e executivo traduzida em números

A tramitação dos acordos internacionais é por si só um processo peculiar e repleto de detalhes, sendo um processo de relação entre os poderes Legislativo e Executivo, os quais precisam atuar dentro de suas competências e cooperar para que se concretizem os objetivos da Política Internacional. Os impactos dessa relação, quer seja a aprovação ou rejeição dos acordos, serão sentidos pelos cidadãos dos Estados Soberanos.

A pujança da atividade diplomática é evidente ao se verificar o crescente número de acordos firmados até 2010, passando por uma redução nos anos subsequentes. Identificou-se que pouco mais de trinta por cento desses atos são encaminhados ao Legislativo, não obstante a discricionariedade do Poder Executivo e a existência dos denominados "acordos executivos", os quais, em razão de sua natureza, passam a vigorar sem a apreciação do Congresso Nacional. Nesse ponto, vislumbrou-se a possibilidade de se estabelecer uma comunicação formal a respeito dos atos celebrados que não foram enviados e dos processos de caráter executivo, em benefício da transparência e manutenção da separação dos poderes.

Ainda, a relação entre os poderes foi caracterizada em números, quando se confirmou, mediante a construção das médias de tramitação, que a Câmara dos Deputados exige quase dois anos para concluir sua análise, que o Senado Federal utiliza cerca de quatro meses para tal e que o Poder Executivo não promulga os atos imediatamente, pois precisa ratificar os acordos (o que leva quase um ano).

Ao dividir os acordos em vinte grupos temáticos, foi possível constatar que determinados temas tramitam de forma mais rápida em um colegiado e mais lenta em outro. Com efeito, é possível planejar e definir estratégias de atuação durante a tramitação de tais processos. Outro achado foi a ausência de clareza das ementas enviadas ao legislativo, que resultou no uso da classificação genérica (“cooperação técnica”) pela pesquisa.

Surpreendeu também a inócua função da classificação do "regime de tramitação", o qual teria a finalidade de impor um ritmo mais célere às proposições urgentes, seguidas pelos processos marcados como "prioridade" e, em seguida, pelos processos considerados ordinários. Contudo, ao se testar a influência de tal regime, não se confirmou o propósito a que se presta, encontrando-se um acúmulo de matérias em regime de urgência.

O tempo gasto para elaboração da PDC constitui trinta a quarenta por cento do tempo total de tramitação. Sendo assim, a matéria leva de sessenta a setenta por cento do tempo para tramitar nas demais comissões e no Plenário. Portanto, mesmo decretando-se o regime de urgência, aparentemente o projeto aguarda a deliberação no Plenário, o que caracteriza uma possível fila de matérias em urgência. 
Para tal questão, apresentamos duas vias de solução. A primeira delas seria retirar a necessidade de se deliberar sobre os acordos em Plenário, já que tais deliberações são praticamente simbólicas, alterando-se o regime para "conclusivo". Seguindo-se a forma utilizada no Senado - art. 91 do Regimento Interno do Senado Federal (RISF) —, poder-seia utilizar um fast track, capaz de impor um ritmo mais veloz à tramitação dos acordos, que tramitaram apenas nas comissões, sem prejuízo de recursos para que a matéria fosse levada ao Plenário, dependendo do tema.

A segunda solução, baseada no exemplo da Comissão do Mercosul, seria oferecer atribuições à CREDN, que hoje competem à CCJC e a CFT. Assim, ela ficaria responsável pela análise quanto à constitucionalidade e aos impactos orçamentários dos processos, a fim de obter maior especialização e acelerar a tramitação.

A criação da Comissão do Mercosul, que, ao ter seu desempenho avaliado, demonstrou um ganho em velocidade de tramitação quando passou a ser responsável pela confecção do Projeto de Decreto Legislativo, prerrogativa exclusiva, até então, da CREDN, também mereceu destaque. Vale ressaltar que ainda há espaço para aperfeiçoamento a esse respeito (por exemplo, se fosse adotada a regra de procedimento preferencial do Protocolo Constitutivo do Parlamento do Mercosul).

A pesquisa ratificou, de fato, o alto índice de aprovação dos acordos. Porém, nem todos eles são promulgados pelo Poder Executivo, pois isso não depende só dele. Portanto, o ideal seria que se instituísse entre os poderes uma comunicação formal, tratando-se do status desses atos, assim como do não envio dos acordos.

Desse modo, conseguiu-se materializar em números a relação entre os poderes Executivo e Legislativo, apontaram-se caminhos para o aprimoramento do processo legislativo e para a busca de maior celeridade (apenas nos casos em que isso seja possível, é claro). Um poder isolado não consegue e nem pode desenvolver a política externa, pois a Pátria envolve todos, sendo os acordos internacionais resultados da cooperação dos dois poderes.

\section{REFERÊNCIAS}

ACCIOLY, H. Manual de Direito Internacional Público. 11 ed. rev. São Paulo: Saraiva, 1995. p. 120.

AMARAL, A. R. V. P. O parlamento brasileiro: processo, produção e organização legislativa: o papel das comissões em perspectiva comparada. Dissertação (Mestrado em Ciência Política) - Câmara dos Deputados, Centro de Formação, Treinamento e 
SILVA, R. Q; REGES, C. P. C. Acordo internacional: a relação entre legislativo e executivo traduzida em números

Aperfeiçoamento (Cefor); Instituto Universitário e Pesquisas do Rio de Janeiro (Iuperj), Rio de Janeiro, 2009.

BARBOSA, R. Obras completas de Rui Barbosa. Rio de Janeiro: Ministério da Educação e Saúde, 1903. p. 360. v. 30, t. 1.

BRASIL. Câmara dos Deputados. Parecer da Comissão de Constituição e Justiça e de Cidadania à Consulta n. 4/2004, de 9 de dezembro de 2004. Brasília Disponível em: <http://www.camara.gov.br/sileg/integras/236372.pdf>. Acesso em: 10 mai. 2017.

Câmara dos Deputados. Regimento Interno. 18. ed. Brasília: Câmara dos Deputados, 2017a. Disponível em: <http://bd.camara.gov.br/bd/handle/bdcamara/18847>. Acesso em: 18 set. 2017.

. Câmara dos Deputados. Sistema de informação legislativa (Sileg). Brasília. Disponível em: http://www.camara.leg.br/buscaProposicoesWeb/pesquisaAvancada.

Disponível

Constituição (1988). Constituição: República Federativa do Brasil. 1988. Brasília.

$<$ http://www.planalto.gov.br/ccivil_03/constituicao/constituicaocompilado.htm>. Acesso em: 10 mai. 2017.

Ministério das Relações Exteriores. Atos internacionais: prática diplomática brasileira e manual de procedimentos. Brasília. 2010. Disponível em: <http://daimre.serpro.gov.br/manual-de-procedimentos/manual-de-procedimentos-praticadiplomatica/view >. Acesso em: 17 jul. 2017.

Ministério das Relações Exteriores. Sistema concórdia. Brasília. Disponível em: https://concordia.itamaraty.gov.br/.

Presidência da República. Decreto $n^{\circ} 7.030$, de 14 de dezembro de 2009. Promulga a Convenção de Viena sobre o Direito dos Tratados, concluída em 23 de maio de 1969, com reserva aos Artigos 25 e 66. Disponível em: <http://www.planalto.gov.br/ccivil_03/_ato20072010/2009/decreto/d7030.htm>. Acesso em: 10 jul 2017.

- Presidência da República. Legislação. Brasília. Disponível em: http://www2.planalto.gov.br/acervo/legislacao.

—. Presidência da República. Legislação. Brasília. Disponível em: http://www.planalto.gov.br/ccivil_03/_ato2015-2018/2015/decreto/D8494.htm.

. Senado Federal. Regimento Interno. Brasília. Senado Federal, 2017b. Disponível em: <http://www25.senado.leg.br/web/atividade/regimento-interno>. Acesso em: 18 set. 2017.

Senado Federal. Sistema de tramitação legislativa. Brasília. Disponível em: http://www12.senado.leg.br/hpsenado.

2001.

. Supremo Tribunal Federal. Ação Direta de Inconstitucionalidade, n. 1480. Brasília. 
2009.

Supremo Tribunal Federal. Ação Direta de Inconstitucionalidade n. 1625. Brasília.

CACHAPUZ DE MEDEIROS, A. P. Pareceres dos consultores jurídicos do Itamaraty. Brasília. Senado Federal, 2000. p. 347. v. 3.

A Constituição de 1988 e o poder de celebrar tratados. Revista de Informação Legislativa, Brasília, v. 45, n. 179, jul./set. 2008.

CAMINO, M. E. M. B. Pendências dos poderes legislativo e executivo para a plena inserção de atos internacionais no direito positivo brasileiro (1988-2013). Brasília. 2014. Disponível em: $\quad<$ http://www2.camara.leg.br/documentos-e-pesquisa/publicacoes/estnottec/areas-daconle/tema3/2014_15931.pdf>. Acesso em: 10 mai. 2017.

CAVALCANTI JÚNIOR, L. G. L. A participação do Congresso Nacional no processo decisório dos tratados: a retirada de tramitação dos acordos de promoção recíproca de investimentos. Brasília, 132 f. Dissertação (Mestrado em poder legislativo) - Câmara dos Deputados, Centro de Formação, Treinamento e Aperfeiçoamento (Cefor), 2015.

CHAIMOVICH, M. M. C. Legislativo e Executivo brasileiros na internalização de tratados de Direitos Humanos: convergências e divergências na ditadura e na democracia. 573 p. Tese (Doutorado em Relações Internacionais) - Universidade de São Paulo, Instituto de Relações Internacionais, São Paulo, 2017. Disponível em: <http://www.teses.usp.br/teses/disponiveis/101/101131/tde-14062017-173705/en.php>.

Acesso em: 28 out. 2017.

COSTA, J. M. da. A denúncia unilateral dos tratados internacionais e a necessidade da participação do Congresso Nacional. Âmbito Jurídico, Rio Grande, v. 15, n. 105, out. 2012. Disponível em: <http://www.ambitojuridico.com.br/site/index.php/\%3C?n_link=revista_artigos_leitura\&artigo_id=12215>. Acesso em: 22 set. 2017.

DINIZ, S.; RIBEIRO, C. Acordos internacionais e controle democrático no Brasil. In: DINIZ, S. (Org.). Política externa e o poder legislativo no Brasil pós-Redemocratização. 1. ed. São Carlos: EdUFSCar, 2014. p. 13-34.

FELIÚ, P. R.; ONUKI, J. Unidade partidária e política externa na América Latina. Revista Brasileira de Ciências Sociais, v. 29, p. 125-142, 2014.

GABSCH, R. D. Aprovação de tratados internacionais pelo Brasil: possíveis opções para acelerar o processo. Brasília: Fundação Alexandre de Gusmão, 2010. Disponível em: $<$ http://funag.gov.br/loja/download/724-

Aprovacao_de_Tratados_Internacionais_pelo_Brasil_possIveis_opcoes_para_acelerar_seu_pr ocesso.pdf>. Acesso em: 10 jun. 2017.

GIL, C. A. Métodos e técnicas de pesquisa social. 6. ed. São Paulo: Atlas, 2008.

GOMES, F. de B. C. Produção legislativa no Brasil: visão sistêmica e estratégica no presidencialismo de coalizão. Brasília: Edições Câmara, 2013. Disponível em: <http://bd.camara.gov.br/bd/handle/bdcamara/13756>. Acesso em: 19 jun. 2017. 
SILVA, R. Q; REGES, C. P. C. Acordo internacional: a relação entre legislativo e executivo traduzida em números

JARDIM, T. D. M. Condicionantes impostas pelo Congresso Nacional ao Executivo Federal em matéria de celebração de tratados. 2010. Disponível em: $<$ https://www12.senado.leg.br/publicacoes/estudos-legislativos/tipos-de-estudos/outraspublicacoes/agenda-legislativa/capitulo-13-condicionantes-impostas-pelo-congresso-nacionalao-executivo-federal-em-materia-de-celebracao-de-tratados>. Acesso em: 20 set. 2017.

LYNCH, C. E. C. Tratado, governo e congresso: a referenda de tratados e a possibilidade de sua alteração legislativa no direito público brasileiro. Revista de Informação Legislativa, v. 46, n. 181, p. 195-206, jan./mar. 2009. Disponível em: <http://www2.senado.leg.br/bdsf/handle/id/194902>. Acesso em: 20 set. 2017.

MARIANO, K. L. P. Regionalismo na América do Sul: um novo esquema de análise e a experiência do Mercosul. 1. ed. São Paulo: Cultura Acadêmica, 2015.

MAZZUOLI, V. de O. Poder Executivo não pode denunciar tratados sem participação do Congresso. Consultor Jurídico, 23 fev. 2015. Disponível em: $<$ http://www.conjur.com.br/2015-fev-23/valerio-mazzuoli-executivo-nao-denunciar-tratadoscongresso $>$. Acesso em: 20 set. 2017.

O treaty-making power na Constituição brasileira de 1988: uma análise comparativa do poder de celebrar tratados à luz da dinâmica das relações internacionais. Rev. bras. polít. int., Brasília, v. 44, n. 2, 2001. Disponível em: <http://dx.doi.org/10.1590/S0034$73292001000200005>$. Acesso em: 15 mai. 2017.

MERCOSUL. Protocolo constitutivo do Parlamento do Mercosul. 2005. Disponível em: $<$ https://www.parlamentomercosur.org/innovaportal/file/7555/1/protocolo_pt.pdf $>$. Acesso em: 5 ago. 2017.

MIRANDA, F. C. P. de. Curso de Direito Internacional Público. 9. ed. Revista dos Tribunais, Brasília. 2015.

NUNES, P. H. F. O problema da ratificação e da denúncia dos tratados internacionais no sistema constitucional brasileiro. Cuest. Const., n. 22, p. 115-131, 2010. Disponível em: $<\mathrm{http}: / / \mathrm{www}$.scielo.org.mx/scielo.php?script=sci_arttext\&pid=S1405-91932010000100004>. Acesso em: 23 set. 2017.

OLIVEIRA, D. P. de. Celebração e integração dos tratados internacionais no direito brasileiro. Revista Constituição e Garantia de Direitos, v. 4, n. 1, 2011. Disponível em: $<$ https://periodicos.ufrn.br/constituicaoegarantiadedireitos/article/view/4339>. Acesso em: 12 mai. 2017.

REZEK, J. F. Direito Internacional Público: curso elementar. 12. ed. São Paulo: Saraiva, 2010.

RODAS, J. G. Os acordos em forma simplificada. Revista da Faculdade de Direito da Universidade de São Paulo, São Paulo, v. 68, n. 1, 1973. Disponível em: <www.journals.usp.br/rfdusp/article/download/66702/69312>. Acesso em: 10 set. 2017. 
Tratado internacional só é executório no Brasil depois da promulgação e publicação. 2015. Disponível em: <http://www.conjur.com.br/2015-dez-24/olhar-economicotratado-executorio-depois-promulgacao\#author>. Acesso em: 10 set. 2017.

SCHMITT, S. T. A política externa e o Poder Legislativo: um olhar sobre a Comissão de Relações Exteriores e Defesa Nacional do Senado Federal. Dissertação (Mestrado em Ciência Política) - Faculdade de Filosofia, Letras e Ciências Humanas, Universidade de São Paulo, São Paulo, 2011.

SOUZA, J. R. C. de. A participação do Legislativo na política externa - áreas de economia e Mercosul - nos governos de Fernando Henrique Cardoso e no primeiro governo de Luiz Inácio Lula da Silva. Tese (Doutorado em Ciência Política) - Rio de Janeiro, Universidade do Estado do Rio de Janeiro, 2010. 